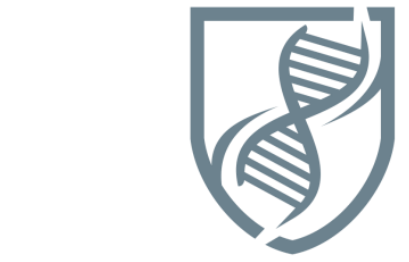

Journal of Bioscience and Applied Research

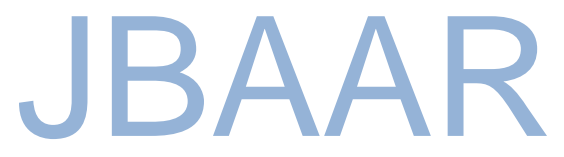

WWW.JBAAR.ORG

\title{
Effects of Occupational Exposure to Pesticides on Male Sex Hormones
}

\author{
Mohga S. Abdallah ${ }^{1}$, Amal Saad-Hussein ${ }^{2}$, Eman M Shahy ${ }^{2}$, Manar Seleem ${ }^{1}$, and Asmaa M. Abdel-Aleem ${ }^{1 *}$ \\ ${ }^{1}$ Department of Chemistry, Faculty of Science, Helwan University and ${ }^{2}$ Department of Environmental \& Occupational \\ Medicine, National Research Centre, Egypt \\ *Corresponding author: E-mail: asmaamohammed199197@yahoo.com
}

DOI: 10.21608/jbaar.2017.125169

\begin{abstract}
Pesticides have been extensively studied for their toxic hazards. The effect of exposure to pesticides has been studied among occupationally exposed workers. This study aimed to determine the role of occupational exposure to pesticides on male reproductive hormones. Follicle Stimulating Hormone (FSH), Luteinizing hormone (LH), and testosterone of 51 pesticide sprayers occupationally exposed to pesticides and 50 controls were estimated. Results revealed a significant increase in FSH concentration among the workers compared to controls. While there was no significant difference in the concentrations of LH and testosterone between the two groups. In conclusion: occupational exposure to pesticides may result in a significant increase of FSH, but not affecting LH and testosterone in the studied pesticide sprayers, and that could be attributed to their use of non-persistent pesticides and the resting durations between the peaks of their occupational exposures.
\end{abstract}

Keywords: Pesticide sprayers; Follicle Stimulating Hormone; Luteinizing hormone; Testosterone.

\section{Introduction}

Pesticides are chemicals used to control agricultural pests and their correct application is the most accepted and effective for maximum production and quality of crops (Martinez and
Gomez, 2007; Mansour, 2008). During the last decades, the use of pesticides has increased steadily in developing countries to increase food production and control of vector-borne 
diseases. There are more than 65,000 chemicals that are classified as pesticides (Mansour, 2008). Because large amounts of these chemicals are released into the environment daily and many of them affect non-target organisms, that has resulted in negative side effects on human health and the environment (Konradsen et al.2003; Hamilton et al.2004).

World Health Organization classified pesticides in various ways such as, by their target, chemical nature, physical state, and mode of action as shown in figure (1). With the banning of most Organochlorines (OCs) pesticides, other types of compounds came into widespread use. The largest group of insecticides currently used globally includes Organophosphates (OPs), which have both agricultural and residential uses (Weiss et al., 2004), and they are readily available commercially for domestic and industrial purposes (Aardema et al., 2008). OPs are the generic term that includes all insecticides containing phosphorus. OPs were considered as a major cause of morbidity and mortality in the third world countries, as a result of poor regulation, monitoring, and even availability of technology and infrastructure (Jaga and Dharmani, 2003).

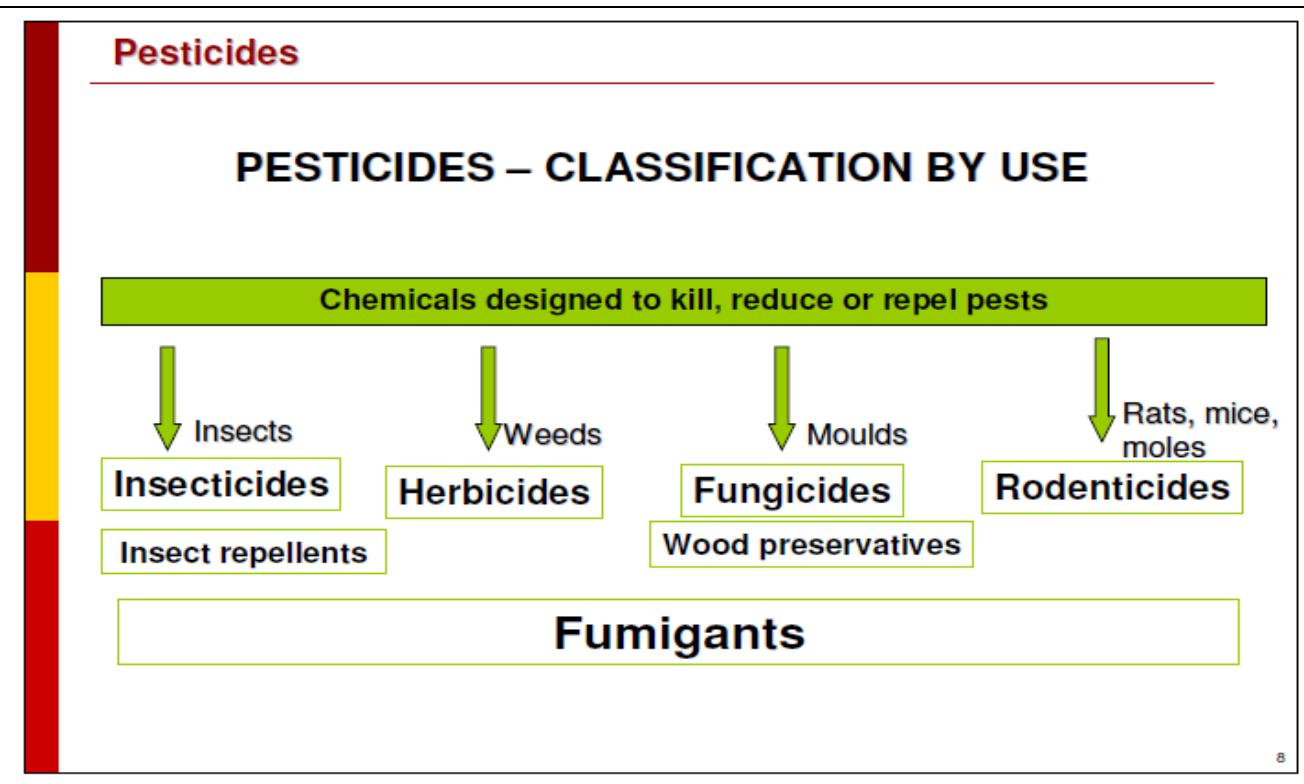

Figure (1): Pesticides classifications by use (WHO. 2008)

World Health Organization report shows that every year about three million deaths occur worldwide related to OPs poisoning (WHO, 2008). There is also toxicological evidence that repeated low-level exposure to OPs may affect neurodevelopment (Gbaruko et al., 2009), immune system (Galloway and Handy, 2003; Li, 2007), and reproduction (Peiris-John and Wickremasinghe, 2008; Fattahi et al., 2009). There is a possibility that the Acephate 
compound; an OP insecticide, could affect the reproductive health of humans and wildlife in their natural habitats (Adachi et al. 2008).

The hormonal balance of male reproductive hormones is an important factor in maintaining fertility and regulating the reproductive process (Kegley et al, 2010). Sex hormones are divided into three classes: androgens (mainly testosterone), estrogens (mainly 17 betaestradiol in the ovarian cycle), and progesterone

(Bhatia et al., 2014). The pituitary gland produces follicle-stimulating hormone (FSH), which stimulates spermatogenesis, and luteinizing hormone (LH), which stimulates androgen production by interstitial cells (Grover et al., 2005). There have been rising concern in many developed countries about the adverse effects of pesticides on the human reproductive system, ranging from female and male sub-fertility to abortion, stillbirths, birth defects, and malformations (Peiris-John \& Wickremasinghe, 2008). The aim of this study is the determination the effects of occupational exposure to pesticides on male reproductive hormones.

\section{Methodology}

\section{Subjects:}

A cross-section comparative study was conducted. The study included two groups; 51 agriculture pesticide sprayers for more than 5 years, and 50 control subjects not occupationally exposed to pesticides and matched in age, special habits, and socioeconomic status.

\section{Questionnaire:}

All enrolled participants were fulfilling personal, environmental, and occupational questionnaires during an individual interview. The personal questionnaire included age, gender, and smoking habits. An environmental questionnaire is designed to exclude from the workers those exposed to huge amounts of pesticides from sources other than occupations, and to exclude from the control group those exposed to a huge amount of pesticides in their environment or through their work. The occupational questionnaire contained a type of the pesticides used mostly, the way of exposure, the duration of exposure in years and days every year, using personal protective equipment and safety measures, and way of application.

Moreover, the biomarkers of exposure (acetylcholinesterase: $\mathrm{AChE}$ and butyrylcholinesterase: $\mathrm{BuChE}$ ) of the pesticides 
sprayers were significantly lower than that of their

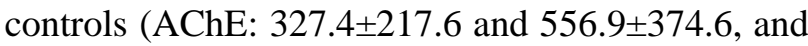
for BuChE: $616.7 \pm 561.1$ and $3700.2 \pm 1050.9$ respectively), as proved in the previous study done on the same selected groups (Noshy et al., 2017).

\section{Laboratory investigation}

About $3 \mathrm{ml}$ of the venous blood samples were collected from all the included workers and controls to determine levels of testosterone, $\mathrm{LH}$, and FSH in the serum. All samples were stored at $-70{ }^{\circ} \mathrm{C}$ until an assessment of the biomarkers.

\section{Male sex hormones;}

- Testosterone was estimated by an ELISA kit (Chen et al., 1991).

- LH was estimated by ELISA kit (Knobil., 1980).

- FSH was estimated by ELISA kit (Uotila et al., 1981).

\section{Statistical Methods:}

Statistical analysis of the collected data and the laboratory results were performed with SPSS version 18. Comparisons between the exposed workers and their controls were done through an Independent t-test, and Pearson correlation coefficients were used to test the association between different parametric variables. MannWhitney $\mathrm{U}$ test was used in comparisons of nonparametric variables. P-value $\leq 0.05$ was considered to be significant. Tabulation and figures were illustrated using the excel program.

\section{Results}

- Socio-demographic criteria of the study groups

Analysis of questionnaires revealed that All the examined subjects in this study were males. There was no significant difference in the age between the workers and the controls (35.4 \pm 11.8 and $33.4 \pm 7.5$ years respectively). About $35.3 \%$ of the workers and $32 \%$ of the controls were smokers without a significant difference between the two groups. Workers included in the present study were exposed to pesticides during their working days for more than 5 years $(9.8 \pm 3.5$ years), and inform of $141.5 \pm 80.6$ days/ year.

Table (1) revealed that the workers were exposed to pesticides during their working days through inhalation, skin contact, and accidental ingestion $(94.1 \%, 100 \%, 52.9 \%$ respectively. Ingestion exposure was accidental from contaminating their work through their meals during working hours, but not to level to have symptoms of acute poisoning. Their exposure to pesticides during different work tasks as Storage, Transportation, Mixing, and Application. During daily work, less than 50\% of the pesticide workers wear personal protective equipment (PPE), while, 62\% of them wear special clothes as shown in. 
Table1: Characteristics data of workers population

\begin{tabular}{|c|c|c|}
\hline $\begin{array}{l}\text { Characteristic of workers } \\
\text { population }\end{array}$ & No. (51) & $(\%)$ \\
\hline $\begin{array}{l}\text { Route of exposure } \\
\text { - inhalation } \\
\text { - skin contact } \\
\text { - ingestion* }\end{array}$ & $\begin{array}{l}48 \\
51 \\
27\end{array}$ & $\begin{array}{c}94.1 \\
100 \\
\mathbf{5 2 . 9}\end{array}$ \\
\hline $\begin{array}{l}\text { Working tasks } \\
\text { - Storage } \\
\text { - Transportation } \\
\text { - Mixing } \\
\text { - Application }\end{array}$ & $\begin{array}{l}29 \\
33 \\
35 \\
30\end{array}$ & $\begin{array}{l}56.9 \\
64.7 \\
68.6 \\
58.8\end{array}$ \\
\hline $\begin{array}{l}\text { Using (PPE). } \\
\text { - Special cloths } \\
\text { - Boots } \\
\text {-Musks } \\
\text {-Gloves }\end{array}$ & $\begin{array}{c}31 \\
18 \\
3 \\
0\end{array}$ & $\begin{array}{c}61.5 \\
34.6 \\
5.8 \\
0.0\end{array}$ \\
\hline $\begin{array}{l}\text { Dealing Way of (PPE). } \\
\text { - re-use } \\
\text { - Washing after use } \\
\text { - Washing with family clothes }\end{array}$ & $\begin{array}{l}47 \\
44 \\
12 \\
\end{array}$ & $\begin{array}{r}92.3 \\
86.5 \\
23.1 \\
\end{array}$ \\
\hline $\begin{array}{l}\text { Wrong habits } \\
\text {-Eating during work } \\
\text {-Smoking during work } \\
\text {-Not change their clothes } \\
\text {-Using an empty container for } \\
\text { storage of food }\end{array}$ & $\begin{array}{c}27 \\
18 \\
31 \\
8\end{array}$ & $\begin{array}{l}52.9 \\
35.0 \\
61.5 \\
15.6\end{array}$ \\
\hline
\end{tabular}

\section{- Biochemical analysis}

In this study, table (2) showed that there was a significant increase in FSH concentration in workers compared to controls. On the other hand, LH and testosterone concentrations showed no significant difference between the workers and their control.

Table 2: Comparison between the biomarkers of exposure and the concentration of male sex hormones in pesticide workers and their controls

\begin{tabular}{|c|c|c|c|}
\hline & Control (50) & Workers (51) & \multirow{2}{*}{$P$-value* } \\
\cline { 2 - 3 } Group Statistics & Mean \pm SD & Mean \pm SD & \\
\hline FSH $(\mathrm{mIU} / \mathrm{ml})$ & $3.9 \pm 1.02$ & $11.3 \pm 2.7$ & P<0.001 \\
\hline LH $(\mathrm{mIU} / \mathrm{ml})$ & $9.6 \pm 6.3$ & $10.8 \pm 5.2$ & 0.099 \\
\hline Testosterone $(\mathrm{ng} / \mathrm{ml})$ & $2.7 \pm 2.1$ & $3.4 \pm 3.1$ & $\mathbf{0 . 9 4 6}$ \\
\hline
\end{tabular}

*P-value was calculated using independent Mann-Whitney U test 
Table (3) showed that there were no significant correlations between studied male hormones and the duration of exposure, for both the number of days per year or the number of years.

Table (3) Correlation between the duration of exposure and the concentration of male sex hormones among the exposed workers

\begin{tabular}{|l|c|c|c|c|}
\hline \multirow{2}{*}{} & \multicolumn{2}{|c|}{$\begin{array}{c}\text { Duration of exposure } \\
\text { (days/year) }\end{array}$} & \multicolumn{2}{c|}{$\begin{array}{c}\text { Duration of } \\
\text { exposure (years) }\end{array}$} \\
\cline { 2 - 5 } & $\mathbf{r}$ & P-value & r & P-value \\
\hline FSH (mIU/ml) & 0.2 & 0.19 & 0.1 & 0.25 \\
\hline LH (mIU/ml) & 0.1 & 0.23 & 0.1 & 0.22 \\
\hline Testosterone (ng/ml) & 0.1 & 0.57 & 0.2 & 0.17 \\
\hline
\end{tabular}

\section{Discussion}

The primary routes by which pesticides enter the body are ingestion in food, soil, or water; inhalation, contact through the skin, and eyes. The exposure of pesticides mainly occurs during the mixing and loading of the equipment and the spraying of insecticides with improper handling (Azmi et al., 2006). In this study, it was observed that the workers exposed to pesticides during their working days through inhalation were $(94.1 \%)$, skin contact was (100\%). Their exposure to pesticides during different work tasks was (56.9\%) storage, (64.7\%) transportation, (68.6\%) mixing, $(58.8 \%)$ application.

The farmers who use pesticides have only a little or no access to information about proper use or the precautions needed when handling pesticides. Therefore, they often do not use even the simplest hygienic and protective measures (Maroni et al., 2006). This work showed that during daily work, less than $50 \%$ of the pesticide workers wear some protective equipment (PPE), while, 62\% of them wear special clothes during their working day. These results were in agreement with (Yassin et al., 2002) they reported that rare use of PPE was reported in several studies among Palestinian farmers and among other farmers in developing (Del Prado-Lu.,2007; Corriols et al., 2009) and developed countries (Perry et al.,2002; MacFarlane et al., 2008).

This work showed that the wrong habits of workers, which increase the risk of exposure to pesticides as smoking at work were (35\%), eating during work was (52.9\%), not change their clothes (61.5), and using an empty container of pesticides for storage of food (15.6). These findings were in agreement with other studies in developing countries that have the same habits, showing that, farmers reported smoking while applying pesticides and also having a meal in the field. This increases their risk of exposure to pesticides, (Salameh et al., 
2004; Ergonen et al., 2005; Recena et al., 2006).

Pesticides may act like hormones in the endocrine system and disrupt the function of the natural endogenous hormones, when doing so they are often called endocrine-disrupting chemicals (EDC) (Diamanti-Kandarakis et al., 2009). Exogenous compounds that alter the normal functioning of the endocrine system are called EDCs, based on several in vitro and in vivo studies, among them are several pesticides (Andersen et al., 2008). Several pesticides were proved to have adverse effects on male reproductive hormones experimentally and epidemiologically (Slimani et al., 2011).

Many studies have denoted that $\mathrm{AChE}$ and BuChE activities have been used as primary biomarkers of pesticide exposure, especially in the field of occupational exposures (Noshy et al., 2017; Saad-Hussein et al., under reviewing), as well as in medical emergencies in cases of clinical and accidental poisoning from OPs and/or carbamates (CB) exposure (Simoniello et al., 2010; Ueyama et al., 2010). The main mechanism of action of OP and CB compounds is inhibition of $\mathrm{AChE}$ or $\mathrm{BuChE}$ to different degrees (Costa et al., 2005), depending on the intensity and duration of exposures (Araoud et al., 2011). This inhibition; especially of $\mathrm{AChE}$, will lead to an increase in acetylcholine, and this increase may lead to inhibition of the release of gonadotrophin-releasing hormone, that inhibits the release of LH and FSH (Terasawa and Fernandez, 2001). In the present study, occupational exposure to pesticides leads to significant elevation in the serum levels of FSH in the exposed workers compared to their controls, but this elevation did not affect significantly the level of testosterone. This could be attributed that there was no significant elevation in the LH levels in the exposed workers compared to their controls. This was against what was proved in previous studies, this could be attributed to the situation of the studied sprays work only $141.5 \pm 80.6$ days per year, even they are working for more than 5 years. These resting days result in the excretion of the high levels of pesticides from the body and to the recovery of their $\mathrm{AChE}$ and $\mathrm{BuChE}$ levels to do their proper work, as OPs are nonpersistent pesticides, and do not accumulate in the body over a long period.

In conclusion: occupational exposure to pesticides may result in a significant increase of $\mathrm{FSH}$, but not affecting $\mathrm{LH}$ and testosterone in the studied pesticide sprayers, and that could be attributed to their use of non-persistent pesticides and the resting durations between the peaks of their occupational exposures. 


\section{References}

Aardema H, Meertens JHJM, Ligtenberg JJM, Peters-Polman OM, Tulleken JE, Zijlstra JG. (2008). Organophosphorus pesticide poisoning: cases and developments. The Netherlands J. Med; 66(4): 149-153.

Adachi N, Kinoshita H, Nishigushi M, Takahashi M, Ouchi H, Minami T, Matsui K, Yamamura T, Motomura $\mathrm{H}$, Ohtsu N, Yoshida S, Hishida S. (2008): Simultaneous analysis of acephate and methamidophos in human serum by improved extraction and GCMS. Forensic Toxicol; 26: 76-79.

Andersen HR, Schmidt IM, Grandjean P, Jensen TK, Budtz-Jorgensen E, Kjaerstad MB, Baelum J, Nielsen JB, Skakkebaek NE, Main KM. (2008). Impaired reproductive development in sons of women occupationally exposed to pesticides during pregnancy. Environ. Health Perspect; 116: 566-572.

Araoud M, Neffeti F, Douki W, et al. 2011 Factors influencing plasma butyrylcholinesterase activity in agricultural workers. Annales De Biologie Clinique (Paris) 69 159-166.

Azmi MA, Naqvi SN, Azmi MA \&Aslam M 2006 Effect of pesticide residues on health and different enzyme levels in the blood of farm workers from Gadap (rural area) KarachiPakistan. Chemosphere 64 (10) 1739-1744.

Bhatia A, Sekhon HK, Kaur G. (2014). Sex Hormones and Immune Dimorphism. The Scientific World Journal; 2014, Article ID 159150: 8 pages.

Chen A, Bookstein JJ \& Meldrum DR 1991 Diagnosis of a testosterone-secreting adrenal adenoma by selective venous catheterization. Fertility and Sterility 55 1202-1203.

Corriols M, Marin J, Berroteran J, Lozano LM, Lundberg I. (2009). Incidence of acute pesticide poisonings in Nicaragua: a public health concern. Occup Environ Med; 66:205-210.
Costa LG, Cole TB, Vitalone A, Furlong CE. (2005). Measurement of Paraoxonase Status as a Potential Biomarker of Susceptibility to Organophosphate Toxicity. Clinica Chimica Acta; 352: 37-47.

Del Prado-Lu JL. (2007). Pesticide exposure, risk factors and health problems among cutflower farmers: a cross sectional study. J Occup Med Toxicol; 2:9. doi: 10.1186/17456673-2-9.

Diamanti-Kandarakis E, Bourguignon JP, Giudice LC, Hauser R, Prins GS, Soto AM, Zoeller RT, Gore AC. (2009). Endocrinedisrupting chemicals: an Endocrine Society scientific statement. Endocr Rev; 30(4):293342.

Ergonen AT, Salacin S, Ozdemir MH. (2005). Pesticide use among greenhouse workers in Turkey. J Clin Forensic Med; 12:205-208.

Fattahi E, Parivar K, Gholam S, Jorsaraei A, Moghadamnia AA. (2009). The effect of diazinon on testosterone, $\mathrm{FSH}$ and $\mathrm{LH}$ levels and testicular tissue in mice. Iran J. Reprod. Med; 7: 59-64.

Galloway T, Handy R. (2003). Immunotoxicity of organophosphorous pesticides. Ecotox; 12(14): 345-363.

Gbaruko BC, Ogwo EI, Igwe JC, Yu H. (2009). Organophosphate induced chronic neurotoxicity: Health, environmental and risk exposure issues in developing nations of the world. Afr. J. Biotech;8(20): 5137-5141.

Grover A, Smith CE, Gregory M, Cyr DG, Sairam MR, Hermo L. (2005): Effects of FSH receptor deletion on epididymal tubules and sperm morphology, numbers, and motility. Mol Reprod Dev; 72(2):135-44. 
Hamilton D, Ambrus A, Dieterle R, Felsot A, Harris C, Petersen B, Racke K, Wong SS, Gonzalez R, Tanaka K, Earl M, Roberts G, Bhula R. (2004). Pesticide residues in food-acute dietary exposure. Pest Manag Sci; 60:311-339.

Jaga K, Dharmani C. (2003). Sources of exposure to and public health implications of organophosphate pesticides. Am. J. Pub. Health; 14(3): 171-185.

Kegley SE, Hill BR, Orme S, Choi AH. (2010). PAN pesticide database., Pesticide Action Network, North America. San Francisco. http: www.pesticideinfo.org

Knobil E 1980 The neuroendocrine control of the menstrual cycle, Recent Progress in Hormone Research 36 52-88.

Konradsen F, van der Hoek W, Cole DC, Hutchinson G, Daisley $\mathrm{H}$, Singh S, Eddleston M. (2003). Reducing acute poisonings in developing countries-options for restricting the availability of pesticides. Toxicology; 192:249-261.

Li Q. (2007). New mechanism of organophosphorus pesticide- induced immunotoxicity. Review. J. Nippon Med. Sch; 74(2): 92-105.

MacFarlane E, Chapman A, Benke G, Meaklim J, Sim M, McNeil J. (2008). Training and other predictors of personal protective equipment use in Australian grain farmers using pesticides. Occup Environ Med; 65:141-146.

Mansour SA (2008). Environmental impact of pesticides in Egypt. Rev Environ Contam Toxicol.;196:1-51.

Maroni M, Fanetti AC, Metruccio F. (2006). Risk assessment and management of occupational exposure to pesticides in agriculture. Med Lav; 97(2):430-437.
Martinez J, Borja-Aburto V, Lopez-Cervante M, Uribe M, Torres-Sanchez L, Cebrian M E. (2005). Pesticide exposure alters follicle stimulating hormone levels in Mexican agricultural workers. Environ Health Perspect; 113(9): 1160-1163.

Noshy MM, Saad-Hussein A, Shahy EM, ElShorbagy HM, Taha MM, Abdel-Shafy EA 2017. Assessment of Anticholinesterase Toxicity, Oxidative Stress and Antioxidant Status in Carbamate and Organophosphorus Pesticides-Exposed Agricultural Workers. International Journal of Pharmaceutical and Clinical Research; 9(3): 205-209.

Peiris-John R J, Wickremasinghe R. (2008). Impact of low-level exposure to organophosphates on human reproduction and survival. Trans R Soc Trop Med Hyg; 102:239245.

Perry M J, Marbella A, Layde P M. (2002). Compliance with required pesticide specific protective equipment use. Am J Ind Med; 41:70-73.

Recena M C, Caldas E D, Pires D X, Pontes E R. (2006). Pesticides exposure in Culturama, Brazil-Knowledge, attitudes, and practices. Environ Res; 102:230-236.

Saad-Hussein A, Abdallah MS, Shahy EM, Seleem M, Abdel-Aleem AM. (under reviewing). Synergistic Oxidative Effects of Smoking and Pesticides Exposure on Reproductive Male Hormones; Macedonian Journal of Medical Sciences.

Salameh P R, Baldi I, Brochard P, Abi S B. (2004). Pesticides in Lebanon: acknowledge, attitude, and practice study. Environ Res; 94:16.

Simoniello M F, Kleinsorge E C, Scagnetti J A, Mastandrea C, Grigolato R A, Paonessa A M, Carballo M A. (2010). Biomarkers of Cellular Reaction to Pesticide Exposure in a Rural Population. Biomarkers; 15: 52-60. 
Slimani S, Boulakoud MS, Abdennour C 2011 Pesticide exposure and reproductive biomarkers among male farmers from north-east Algeria. Annals of Biological Research 2 290-297.

Terasawa E, Fernandez D L. (2001). Neurobiological mechanisms of the onset of puberty in primates. Endocr Rev; 22: 111-151.

Ueyama J, Satoh T, Kondo T, Takagi K, Shibata E, Goto M, Kimata A, Sait, I, Hasegawa T, Wakusawa S, Kamijima M. (2010). Glucuronidase Activity is a Sensitive Biomarker to Assess Low-level Organophosphorus Insecticide Exposure. Toxicology Letters; 193: 115-119.

Uotila M, Ruoslahti E \&Engvall E. J 1981.

Weiss B, Amler S, Amler R W. (2004). Pesticides. Pediatrics; 113(4):1030. 7.

World Health Organization, WHO (2008). Children's Health and the Environment. WHO Training Package for the Health Sector. www.who.int/ceh

Yassin M M, Abu Mourad T A, Safi J M. (2002). Knowledge, attitude, practice, and toxicity symptoms associated with pesticide use among farmworkers in the Gaza Strip. Occup Environ Med; 59:387-393. 